ARTIGO

\title{
0 estatuto do trabalho docente no currículo referência de Minas Gerais
}

\author{
Andreia Rezende Garcia-Reis' (D) \\ Giovana Rabite Callian" (D)
}

RESUMO

Este estudo tem como objetivo analisar o texto introdutório do Currículo Referência de Minas Gerais quanto ao estatuto do trabalho docente nele representado e à responsabilidade atribuída ao professor nessa parte do documento. $\mathrm{O}$ quadro teórico-metodológico a que nos filiamos é o do Interacionismo Sociodiscursivo e o procedimento metodológico utilizado é a Semântica do Agir, de modo a investigarmos se o professor concebido pelo Currículo de Referência é ator ou agente em seu agir profissional. Por meio da análise empreendida, podemos afirmar que o documento estabelece relações intertextuais com a Base Nacional Comum Curricular e atribui ao professor a reponsabilidade de executar o projeto de ensino nele prescrito, concebendo-o como agente e não como ator em sua atividade profissional.

\section{PALAVRAS-CHAVE}

trabalho docente; currículo referência de Minas Gerais; semântica do agir. 


\section{THE STATUTE OF TEACHING WORK IN THE REFERENCE CURRICULUM OF MINAS GERAIS}

\section{ABSTRACT}

The purpose of this study was to analyze the introductory text of the Reference Curriculum of the state of Minas Gerais regarding the regulation of a teacher's work included in it and the responsibility assigned to the teacher in this part of the document. The theoretical-methodological framework to which we are affiliated is that of the Socio-Discursive Interactionism, and the methodological procedure used is the Semantics of Acting in order to investigate if a teacher as conceived by the Reference Curriculum is an actor or an agent in their professional acting. From this analysis, we can state that the document establishes intertextual relations with the Common National Curriculum Base and assigns the teacher with the responsibility of applying the teaching project as prescribed therein, conceiving the teacher as an agent and not as an actor in his professional activity.

KEYWORDS

teaching work; reference curriculum of the state of Minas Gerais; semantics of acting.

\section{EL ESTADO DEL TRABAJO DOCENTE EN EL CURRICULUM DE REFERENCIA DE MINAS GERAIS}

\section{RESUMEN}

Este estudio tiene como objetivo analizar el texto introductorio del Currículo de Referencia de Minas Gerais con respecto al estado del trabajo docente allí representado y la responsabilidad atribuida al profesor en esta parte del documento. El cuadro teórico-metodológico al que estamos afiliados es el del Interaccionismo Sociodiscursivo y el procedimiento metodológico utilizado es la Semántica de Agir, para investigar si el profesor concebido por el Currículo de Referencia es un actor o agente en su acto profesional. A partir del análisis realizado, podemos afirmar que el documento establece relaciones intertextuales con la Base del Currículo Nacional Común y asigna al profesor la responsabilidad de ejecutar el proyecto de enseñanza allí prescrito, concibiéndolo como un agente y no como un actor en su actividad profesional.

PALABRAS CLAVE

trabajo docente; currículo de referencia de Minas Gerais; semántica del actuar. 


\section{INTRODUÇÃO}

Este artigo trata da análise do texto introdutório de um documento oficial, o Currículo Referência de Minas Gerais, editado pela Secretaria de Estado de Educação de Minas Gerais (Minas Gerais, 2018), recentemente homologado, que tem por função prescrever o trabalho docente, uma vez que indica, de forma explícita ou implícita, as tarefas que devem ser realizadas pelos trabalhadores, apresentando elementos para a atividade profissional docente nas escolas estaduais de Minas Gerais.

Nossa análise está inserida no quadro teórico-metodológico do Interacionismo Sociodiscursivo (doravante ISD) e incide sobre o referido documento, buscando identificar o estatuto do trabalho docente delineado nos textos introdutórios do Currículo Referência de Minas Gerais e que tipo de responsabilidade é atribuída ao professor.

Assim, analisaremos, a partir de excertos retirados do documento e contextualizados em sua completude, o agir docente nele descrito a partir da Semântica do Agir (Bronckart, 2008), procedimento metodológico do ISD que busca nomear determinadas interpretações sobre os actantes e sobre o seu agir, presentes em um texto, e a partir delas definir quem são os reais atores, aqueles dotados de razões, responsabilidades e intenções para seu agir, e aqueles que se configuram como agentes do processo, quando as atribuições para o agir lhes são negadas (Machado e Bronckart, 2009). Objetivamos, assim, contribuir para o esclarecimento das concepções sobre o estatuto do trabalho docente que esse texto veicula e o real papel atribuído aos professores.

Para melhor compreensão do trabalho docente, são necessários estudos que contemplem textos desse tipo, uma vez que a questão das prescrições tem estado ausente das pesquisas que buscam analisar o ensino ou o trabalho do professor, como se elas não interferissem na ação de ensinar (Amigues, 2004). Em consonância com o autor, acreditamos que a análise desses textos prescritivos corrobora sobremaneira a apreensão das propriedades do trabalho educativo.

Assim, subdividimos o texto em dois momentos. Inicialmente, vamos discorrer sobre o contexto de produção do referido documento, visto que essa análise inicial nos fornecerá informações sobre o aspecto sócio-histórico que precedeu a elaboração do Currículo Referência de Minas Gerais, permitindo uma leitura mais contextualizada e menos inocente do documento, bem como do tratamento direcionado ao professor e seu trabalho (Bronckart e Machado, 2004). Em seguida, traremos considerações sobre o ISD, que poderá nos fornecer dados sobre o trabalho docente e para a compreensão da atividade educacional e do agir docente em toda a sua complexidade. Abordaremos também, nesse conjunto, o trabalho prescrito e suas implicações para o trabalho docente. Apresentaremos a metodologia de análise utilizada - Semântica do Agir — para responder as nossas problemáticas, procedimento que Bronckart e Machado (2004) definem como mais interpretativo, e as terminologias que utilizaremos para definir determinados conceitos relativos a esse dispositivo de análise. Na sequência, teceremos interpretações de excertos retirados do documento e finalizaremos com a conclusão sobre os dados fornecidos pela análise. 
Consideramos que esta pesquisa traz contribuições relevantes sobre o trabalho docente, além de servir também para atualizar as pesquisas desenvolvidas sobre a análise de textos prescritivos a partir do viés do ISD, ampliando as leituras sobre esse tema.

\section{CONTEXTO DE PRODUÇÃO DO CURRÍCULO REFERÊNCIA DE MINAS GERAIS}

Nesta seção, buscamos trazer alguns dados sobre o contexto sociointeracional de produção do texto que será analisado por meio do levantamento de informações externas ao texto, permitindo uma leitura mais crítica do documento.

É importante ressaltar que, mais recentemente, algumas pesquisas têm direcionado seus estudos para análise de textos produzidos por instituições governamentais que buscam orientar e prescrever o trabalho docente. De acordo com Bronckart (2008), esses textos, no início das suas pesquisas, foram chamados de "textos prescritivos do trabalho educacional", expressão consagrada pelos ergonomistas da clínica da atividade e comumente utilizada para outras situações de trabalho.

Bronckart (2008) identificou, em um primeiro estudo sobre esses textos, que a dimensão de prescrição não está presente de forma explícita nesses documentos e a partir desse dado optou por nomeá-los de textos "prefigurativos". Entretanto, o autor pontua que um exame mais minucioso demonstrou que esses textos têm outras finalidades que vão além de antecipar as formas de agir do professor, por isso, passou a adotar uma nova terminologia para referir-se a eles: textos (ou documentos) do entorno-precedente ao agir (Bronckart, 2008). Dessa forma, neste estudo, trataremos o documento Currículo Referência de Minas Gerais a partir da terminologia proposta e adotada por Bronckart (2008), considerando-o um documento do entorno-precedente ao agir.

De acordo com Dolz e Gagnon (2015, p. 26), "todo texto é singular, sendo obra de um indivíduo ou de um coletivo em um determinado momento". Entendemos que todo sujeito pertencente a uma comunidade, em variadas situações comunicativas com seus pares, sempre lançará mão de um determinado texto preexistente, que se organiza em um determinado espaço, denominado de arquitextualidade, organizado em gêneros que sofrem diversas transformações no decorrer do tempo (Bronckart, 2006). Em vista disso, Dolz e Gagnon (2015) afirmam que, tanto social quanto culturalmente, todo texto é um exemplar de gênero, pois é parte de um construto histórico resultante de uma prática e de uma formação social. Os autores assinalam que para se definir a noção de gênero é fundamental considerar tanto sua ancoragem social como a natureza comunicacional do discurso.

Afirmamos, assim, que textos são correspondentes empíricos/linguísticos das atividades de linguagem de um grupo e de uma determinada ação de linguagem. Dessa forma, o texto se caracteriza como uma ação comunicativa, produto da atividade de linguagem. Esses textos apresentam características relativamente estáveis em função de seus objetivos comunicativos, interesses e questões específicas, o que justificaria serem nomeados de gêneros de textos disponíveis em um intertexto (Bronckart, 2006). 
A respeito dos textos do entorno-precedente ao agir, Bronckart (2008) afirma que há grande dificuldade em delimitar e classificar a que gênero textual pertencem, no entanto, mesmo apresentando um caráter instável em sua organização genérica, eles trazem três propriedades enunciativas consideradas relevantes. Primeiro, eles provêm de um expert que não está presente no texto, sua figura enunciativa é apagada, ou sua menção é feita de forma marginal, muitas vezes por meio de uma assinatura. Segundo, de acordo com o autor, o destinatário é comumente mencionado no texto de forma clara, identificando os actantes das ações prescritas. E, terceiro, esses textos parecem ser redigidos como verdades absolutas e promessas de sucesso, garantindo ao destinatário que, se ele agir conforme as prescrições, alcançará seu objeto maior.

Nesse contexto, consideramos que o Currículo Referência de Minas Gerais (Minas Gerais, 2018), devido ao seu caráter dinâmico e comunicacional, é um documento do entorno-precedente ao agir, discursivo e dialógico, pois está se referindo a um destinatário, no caso, o professor, de modo mais específico. Dessa forma, ancoradas na definição de gênero em uma perspectiva histórico-cultural, também assumida por Bronckart (2006), e a partir das propriedades enunciativas comuns a esses textos, caracterizamos o documento em análise como um gênero textual pertencente à dimensão do entorno-precedente ao agir.

Uma vez filiadas à perspectiva teórico-metodológica do ISD (Bronckart, 2006, 2008), não poderíamos analisar o texto do Currículo Referência de Minas Gerais por uma perspectiva meramente linguística, pois isso não traria dados suficientes para analisarmos o estatuto do trabalho docente presente no referido documento. Optamos então por investigar algumas das dimensões sociais que o texto traz, observando inicialmente seu contexto de produção, por uma perspectiva de análise do plano global, para posteriormente analisarmos as outras relações estruturais que podem ser inferidas, a partir de uma análise mais profunda, que nos fornecerá maiores subsídios para relativizarmos os dados encontrados.

Para o ISD, a análise preliminar deve considerar cinco aspectos importantes. Segundo Machado e Bronckart (2009), o primeiro aspecto refere-se ao contexto sócio-histórico mais amplo em que o texto é produzido, em que circula e é usado; o segundo está relacionado ao suporte em que o texto é veiculado; o terceiro direciona-se ao contexto linguageiro imediato, ou seja, os textos que acompanham, em um mesmo suporte, o texto a ser analisado; o quarto aspecto relevante é o intertexto, os textos com os quais o material analisado mantém relações facilmente identificáveis antes mesmo de qualquer análise; e, por fim, o quinto aspecto, a situação de produção, ou seja, as representações do produtor que exercem influência sobre a forma do texto, distribuídas em tais parâmetros: emissor, receptor, local, tempo, papel social do enunciador e do receptor, instituição social e objetivo da produção. Diante desses aspectos a serem considerados, vamos ao levantamento dessas informações.

Como sabemos, nesses últimos anos o sistema educacional tem passado por uma série de intervenções governamentais guiadas com o objetivo de transformá-lo, com o intuito de melhorar a educação, para que dessa forma ela seja oferecida a todos com qualidade e equidade. Um dos marcos dessas intervenções foi a elaboração da Base Nacional Comum Curricular (Brasil, 2017), homologada em 2017, que passou a servir de referência a outras ações prescritivas, como, por exemplo, o Currículo Referência para o estado de Minas Gerais. 
O referido documento foi elaborado a partir dos fundamentos educacionais expostos na nossa Constituição Federal (Brasil, 1988), na Lei de Diretrizes e Bases da Educação Nacional (LDB no 9.394/96) (Brasil, 1996), no Plano Nacional de Educação (PNE/2014) (Brasil, 2014), na Base Nacional Comum Curricular (BNCC/2017) (Brasil, 2017) e a partir do reconhecimento e da valorização dos diferentes povos, culturas, territórios e tradições existentes em nosso estado (Minas Gerais, 2018). Observamos, de acordo com o próprio documento, que ele é resultado de intenso trabalho em regime de colaboração entre a Secretaria de Estado de Educação de Minas Gerais (SEE/MG) e a União Nacional dos Dirigentes Municipais de Educação, seccional Minas Gerais (UNDIME/MG), e contou com a participação de professores em todo o estado de Minas Gerais. Para a sua formulação, conforme o texto inicial do documento, foram considerados e estudados os documentos curriculares já presentes em diferentes redes (estadual e municipais) como fonte de inspiração para a elaboração de um currículo que pudesse ser referência em todo o estado de Minas Gerais.

De acordo com informações retiradas de um site de divulgação do documento ${ }^{1}$, em dezembro de 2018, foi entregue ao Conselho Estadual de Educação (CEE/MG) e à União dos Conselhos Municipais de Educação, seccional de Minas Gerais (UNCME/MG) um parecer indicando a adesão dos municípios mineiros ao novo documento. O Secretário de Estado Adjunto de Educação fez a homologação do parecer, e a primeira etapa para a implementação do Currículo Referência de Minas Gerais foi a elaboração de normativa específica para sua regulamentação, substituindo a Resolução no 666/2005 (Minas Gerais, 2005), referente ao Currículo Básico Comum (CBC).

Ainda segundo o mesmo site, a Coordenação Estadual do Currículo iniciou a elaboração da normativa que foi disponibilizada no início do ano de 2019 , assinalado como ano de transição para que as escolas se adaptassem ao novo modelo curricular proposto. $\mathrm{O}$ material ainda não deveria ser considerado para fins de organização escolar, mas utilizado para a formação de professores e gestores da educação, na reelaboração dos projetos pedagógicos das escolas e na revisão dos processos de avaliação.

O Currículo Referência de Minas Gerais teve seu processo de construção no momento de definição da Base Nacional Comum Curricular com vistas a atender a todo o país. Esses documentos que preconizam uma "reforma educacional" - pois trazem críticas sistemáticas relacionadas à escola e aos modelos tradicionais de transmissão dos saberes que devem ser abandonados para se privilegiar os processos de aprendizagem centrados na criança - foram elaborados "em um momento político-econômico brasileiro bastante caótico" (Jacob, Diolina e Bueno, 2018, p. 90), no qual várias manifestações culminaram com a destituição do cargo de uma presidente legitimamente eleita para a posse do vice-presidente e o país passou a ser

1 Disponível em: https://www.google.com/url?q=https\%3A\%2F\%2Fcurriculoreferencia. educacao.mg.gov.br\&sa=D\&sntz=1\&usg=AFQjCNGVsr0VUQzzPUTt2hvkJ_0Mq w9Iyw. Acesso em: 5 jun. 2019. 
governado por uma política inspirada na ideologia neoliberal (Machado e Cristovão, 2009), com severos cortes na saúde, na educação e nas ciências.

De acordo com o próprio documento, foi estabelecido um modelo de governança dinâmico capaz de lidar com as particularidades do estado de Minas Gerais e com entidades que atuam diretamente na melhoria da educação pública. Dessa forma, temos um currículo mineiro que incorpora as diretrizes e normativas da BNCC (Brasil, 2017) e tem como preceito uma educação libertadora de qualidade que promova a inclusão, reconhecendo e valorizando as diversidades (Minas Gerais, 2018).

A organização desse material foi conduzida por grupos de trabalho de currículo que reuniram profissionais de diversas áreas e diversas partes do estado. De acordo com o texto do documento, toda equipe responsável participou de encontros formativos realizados pelo Ministério da Educação (MEC), além de formações internas oferecidas a professores e pesquisadores de universidades mineiras. A sua produção contou também, conforme destaca o próprio documento, com o processo de consulta pública on-line e encontros municipais realizados em diversos municípios em parceria com as redes de ensino, nas quais educadores e comunidade puderam debater sua versão preliminar para fazer contribuições pertinentes e ampliá-la.

As propostas foram analisadas pela equipe de redação quanto à sua pertinência e algumas adequações foram feitas em consonância com o proposto. O documento reforça que grande parte das sugestões foi incorporada, fazendo dele uma representação real da colaboração de diversas partes do território de Minas Gerais. Cabe ressaltar que, embora seja mencionado esse movimento de colaboração e promoção de encontros municipais para discussões sobre essa proposta curricular, não observamos de fato tal movimento nas escolas estaduais do município de Juiz de Fora (MG).

A organização desse documento, conforme já dissemos, foi conduzida por vários especialistas, contratados pela SEE/MG, entretanto, nota-se que essa polifonia, apesar de constituída por experts, é de pessoas externas ao dia a dia do sistema educacional estadual mineiro. Sobre isso, Machado (2009) constata, nos documentos oficiais observados por ela, uma constituição semelhante, em que as prescrições são geralmente elaboradas por agentes externos e impostas aos professores.

Entendemos que há a necessidade de um currículo base e isso contribuirá sobremaneira para os processos educacionais, pois aspectos curriculares mínimos em uma tentativa de dizer que há elementos e objetivos de aprendizagem que deveriam ser alcançados por todas as escolas são necessários. Dessa forma, acreditamos que um currículo mínimo de referência que aponte alguns princípios da aprendizagem e ofereça garantias mínimas para assegurar os direitos de aprendizagem dos alunos pode ser, sim, idealizado e proposto pelas entidades governamentais. No entanto, isso se constitui em grande desafio diante da heterogeneidade da população inserida nas escolas e das próprias escolas, dos professores e do trabalho docente ali realizado.

Com relação ao intertexto, observamos que, em um primeiro momento, a Secretaria de Estado de Minas Gerais toma emprestado um gênero textual presente no arquitexto para produzir o Currículo Referência de Minas Gerais. Assim, o documento se configura a partir de um elo intertextual (Machado e Bronckart, 
2009) com a BNCC (Brasil, 2017), pois mantém com ela relações facilmente identificáveis. Segundo Garcia-Reis e Godoy (2018), a BNCC caracteriza-se como um documento norteador do ensino, no qual delineiam-se as aprendizagens consideradas essenciais a serem trabalhadas para o desenvolvimento dos estudantes. Cabe ressaltar, de acordo com o texto da quarta versão da BNCC, que ela não é um currículo, contudo poderá servir de referência nacional para a formulação dos currículos das redes estaduais, distritais e municipais do país (Garcia-Reis e Godoy, 2018). A partir disso, entendemos que o Currículo Referência de Minas Gerais teve sua formulação a partir da BNCC.

Após essa contextualização sociointeracional de produção do documento, seguimos para a escolha dos segmentos, a partir da leitura do texto introdutório, que revelam o estatuto do trabalho docente. Para embasar essas análises sobre o trabalho do professor presente no texto selecionado, buscamos, antes, definir alguns conceitos e clarificar a perspectiva teórico-metodológica que adotamos, na seção seguinte.

\section{O INTERACIONISMO SOCIODISCURSIVO: TRABALHO DOCENTE E TRABALHO PRESCRITO}

No Brasil, diversos autores, como Machado (2007, 2009), Machado, Abreu-Tardelli e Cristovão (2009), Magalhães e Cristovão (2018), entre tantos outros, têm voltado seus estudos para o ISD e desenvolvido pesquisas que o utilizam como referencial para analisar o funcionamento e o desenvolvimento das condutas humanas, contribuindo para a ampliação do seu quadro teórico-metodológico.

Entre essas pesquisas, aquelas que analisam documentos produzidos por instâncias governamentais com o foco em orientações ou prescrições para o trabalho educacional têm apontado lacunas e imprecisões nesses documentos com relação ao trabalho docente (Amigues, 2004), ora escamoteando a figura do docente, ora tratando-o como mero agente, ora atribuindo-lhe muitas competências e funções que sobrecarregam o seu trabalho, causando um mal-estar docente e uma crise de identidade com relação à sua profissão. Devido a essas lacunas e imprecisões, é fundamental a análise desses documentos a partir de um olhar mais crítico, a fim de nos apropriarmos das particularidades do trabalho educativo propostas e contribuirmos com considerações pertinentes sobre esse métier.

Machado (2007) destaca que o conceito de trabalho tem sido muito discutido no campo das Ciências Humanas nos últimos anos, pois os estudos feitos anteriormente não são suficientes para abarcar as variadas formas de trabalho presentes na sociedade contemporânea. Nesse viés, Machado e Bronckart (2009) reforçam que, para chegarmos a detectar as figuras interpretativas do agir em textos no e sobre o trabalho educacional, precisamos definir um conceito sobre trabalho docente, mesmo que provisório, para posteriormente ampliá-lo a partir das fundamentações e discussões travadas.

De uma maneira mais geral, o trabalho, como é sustentado por Machado e Bronckart (2009), é uma atividade pessoal e única, pois envolve todas as dimensões do trabalhador, sejam elas físicas, mentais, práticas, emocionais etc.; é também im- 
pessoal, uma vez que as tarefas são prescritas ou prefiguradas por instâncias externas; é interacional e mediada por instrumentos materiais ou simbólicos utilizados pelos trabalhadores que ao agirem sobre o meio o transformam e são por ele transformados; é interpessoal, pois envolve sempre interação com outros indivíduos direta ou indiretamente; e, ainda, transpessoal, pois é sempre guiada por "modelos do agir" específicos de cada profissão.

Saujat (2004) aponta que muitas concepções defendem que todo ato de ensino provém de uma tomada de decisão, seja ela consciente ou não, dos professores, feita sempre após o tratamento dado a uma informação complexa que será transposta em conhecimento disponível. Essa perspectiva acaba construindo uma imagem errônea do professor, a de um ser que espera determinados acontecimentos ocorrerem em sala de aula para reagir, fazendo escolhas a partir de um repertório de respostas possíveis. $O$ professor, nessa perspectiva, constitui-se em um ser racional, que avalia qual o meio mais adequado para oferecer as respostas concebidas mentalmente (Saujat, 2004).

Assim como o autor, consideramos essa concepção infundada, pois as decisões racionais não são necessariamente a base da atividade de ensino. Na sala de aula, quase sempre, não há tempo para a demora na tomada de decisões. O pensamento profissional surge a partir de uma reflexão no curso da ação, reflexão que incide sobre a ação e sobre a conduta em um determinado contexto. Essa postura deve estar incorporada no indivíduo e é a fonte da eficiência da atividade profissional, capaz de estabelecer um diálogo dos profissionais com os problemas que encontram no seu dia a dia.

Nesse sentido, Saujat (2004) constata que, ao relacionarmos o trabalho docente aos acontecimentos decorrentes de uma aula - múltiplos e simultâneos, marcados por imediatismos e rapidez, imprevisíveis e públicos -, percebemos que o agir docente deve partir de uma reflexão em curso da ação. Destacamos ainda que esse processo de ensino requer uma base de conhecimentos ligados ao agir profissional e uma prática que se desenvolva em diversas situações, por mais complexas que sejam. Os professores também devem dotar-se de capacidades para gerir suas próprias competências e atos, ter autonomia e responsabilidade pessoal no exercício de suas competências, aderir a normas coletivas que constituem sua identidade profissional e pertencer a um grupo que desenvolva estratégias de promoção e de valorização, adquirindo estilos pedagógicos (pessoal, relacional, intencional e didático) (Saujat, 2004).

Todas essas características mostram o quão complexa é a atividade de trabalho docente. Ela envolve escolhas permanentes feitas pelos sujeitos envolvidos, conflitos entre seu modo de agir e prescrições que orientam sua atividade. Dessa forma, como afirma Clot (2007), o agente das prescrições não deve ser concebido como mero executor da tarefa prescrita, pois essa tarefa está inserida em sua história. Assim, devemos considerar que o professor não só realiza as prescrições presentes nos documentos como um simples agente, mas deve ser considerado como um ator do processo de ensino.

Saujat (2004) identifica que o ensino é um tema muito abordado, devido ao grande número de pesquisas que lhe são consagradas, entretanto, não sabemos 
quase nada sobre ensino como trabalho. Na mesma perspectiva, Bronckart (2006, p. 203) afirma que só "há alguns anos, a atividade de ensino tem sido considerada como um verdadeiro trabalho" e merece um esclarecimento maior. Portanto, entendemos que estamos diante de um novo objeto de estudo, visto que até pouco tempo atrás o trabalho docente não era considerado uma forma de trabalho, e sim um dom ou uma vocação.

De acordo com Machado et al. (2009), pesquisas sobre o trabalho docente são extremamente necessárias, pois, como foi constatado, há grande lacuna a ser preenchida que tome o ensino na sua dimensão de trabalho e em uma abordagem discursiva. A necessidade de analisar textos no e sobre o trabalho educacional é essencial para melhor compreensão desse métier. As autoras somam a isso o fato de serem contra um discurso generalizador impregnado nos textos no/sobre o trabalho docente, que considera o professor como um ser inacabado, a quem sempre "falta" algo para conseguir desenvolver um trabalho eficiente com resultados positivos. $\mathrm{Na}$ tentativa de clarificar alguns aspectos desse métier, Machado et al. (2009) sugerem aprofundamento teórico-metodológico sobre as relações entre linguagem e trabalho educacional, por meio de análises de práticas de linguagem no e sobre esse trabalho, pois elas poderão nos revelar muitos aspectos referentes à influência que exercem nas configurações desse trabalho e também nas significações construídas sobre o professor e seu agir profissional.

Machado et al. (2009) destacam que as ações humanas só podem ser apreendidas por meio de interpretações de linguagem, sejam de textos que se referem a uma determinada atividade social dos próprios actantes ou de observadores dessas ações. Esses textos, conforme apontam, exercem influências sobre as atividades e as ações nelas envolvidas, refletindo representações, interpretações e avaliações sociais sobre essa atividade ou ação. Portanto, as autoras reforçam que, para compreendermos melhor uma atividade educacional, os objetos de análise podem ser os textos desenvolvidos tanto na própria situação de trabalho como sobre essa atividade profissional.

Assim, temos vários tipos de textos que podem ser analisados: os produzidos na situação de trabalho pelo próprio trabalhador, muitas vezes em conjunto com outros actantes; os produzidos antes do trabalho, aqueles que se prefiguram como um "modelo para o agir" adaptado pelo trabalhador de acordo com a sua situação particular, que podem subdividir-se em textos de prefiguração genérica, oriundos do próprio actante ou de outras fontes, e textos de prefiguração específica, referentes ao agir em situação de trabalho, também divididos em duas categorias: aqueles do entorno-precedente ao agir, elaborados por instâncias externas que indicam de forma implícita ou explícita o que deve ser feito, tais como o documento que analisamos - o Currículo Referência de Minas Gerais -, prescritivo do trabalho educacional, e aqueles produzidos pelos próprios trabalhadores sobre seu trabalho antes de realizar uma determinada tarefa (Machado et al., 2009).

As autoras assinalam que, ao agirmos, submetemos esse agir a uma descrição, uma interpretação e/ou avaliação e, por meio da análise dessas interpretações, dessas condutas expostas, conseguimos apreender as ações humanas. 
$\mathrm{Na}$ abordagem de Bronckart (2008), é possível analisar os textos do entorno-precedente ao agir a partir de uma perspectiva de condição de produção. Nessa conceitualização, procura-se delinear e definir a situação em que se encontra todo actante envolvido no processo de produção do texto. Ainda de acordo com o autor, essa situação pode ser observada a partir de uma série de parâmetros físicos do ato de produção - emissor, receptor, espaço-tempo - e de parâmetros sociossubjetivos - tipo de interação social em curso, objetivos possíveis, papéis atribuídos aos protagonistas da interação. Entendemos que esses parâmetros são fundamentais para definir o tipo de agir linguageiro que se materializará no texto que será produzido (Bronckart, 2008).

De acordo com Machado e Bronckart (2005), o trabalho prescrito encontra-se diluído pela instituição escolar e é delineado nos textos do entorno-precedente ao agir que incidirão sobre a organização geral da escola. Esses textos apresentam propriedades enunciativas centrais que os caracterizam de forma bastante explícita. Dentre essas características, podemos ressaltar algumas, como, por exemplo, o fato de serem produzidos por especialistas em um dado campo, cuja presença enunciativa é apagada; também é observado o direcionamento a um destinatário, ou um agente das prescrições, ou seja, aquele que irá colocá-las em prática. Cabe ressaltar que, muitas vezes, essa posição de destinatário pode ser ocupada por vários sujeitos envolvidos no mesmo campo de trabalho.

Evidenciamos também que, geralmente, as prescrições têm o aspecto de "contrato de felicidade" em uma dimensão ideológica (Bronckart, 2008), na qual se explicita uma verdade incontestável e uma promessa de sucesso ao destinatário, que se agir em conformidade com todas as recomendações e respeitando os procedimentos que lhes são indicados, ele alcançará seus objetivos (Machado e Bronckart, 2005). Ou seja, esses textos do entorno-precedente ao agir não trazem descrições sobre os atos concretos que constituem o trabalho docente, mas buscam justificar a utilização de uma nova metodologia, assegurando seus efeitos benéficos para a aprendizagem dos alunos.

Outras características também são destacadas pelos autores, como, por exemplo, a presença de um autor institucional e coletivo, com uma hierarquia claramente expressa e institucionalizada por três protagonistas centrais: o produtor do discurso, $\mathrm{o}$ agente do agir prescrito e o beneficiário desse agir, identificados, respectivamente, por uma entidade institucional, por um educador, professor, ou ainda docente, e por um aluno objeto de investigação do locutor do texto, considerado um tipo-ideal ao qual todo o fazer docente deve estar voltado.

A relação entre esses protagonistas, os quais estão presentes no texto aqui analisado, organiza-se em uma estrutura semelhante à descrita por Machado e Bronckart (2005), na qual a entidade institucional (Secretaria de Estado de Minas Gerais) diz que o professor deve agir para o aluno, caracterizando a prescrição para o trabalho do professor como uma metodologia referente a seu agir em sala de aula.

Os estudiosos reforçam que os textos do entorno-precedente ao agir apresentam um ato de ordem, assim como constatado por nós no documento analisado. Esse ato de ordem é amenizado por justificativas e afirmações de que o documento se propõe a auxiliar o professor, colocando-se à sua disposição, pois ele será bene- 
ficiado com o sucesso do seu trabalho e o aprendizado do aluno. Conforme asseverado por Amigues (2004), a análise desses textos tem estado muito ausente das pesquisas, como se essas prescrições não influenciassem a ação de ensinar, apesar de determinarem, de certo modo, sua realização. Em virtude disso, realizaremos uma análise do texto introdutório do documento recentemente homologado, pensando em contribuir para essas pesquisas e ampliar o campo de estudos do ISD.

Na próxima seção, faremos uma breve exposição teórica sobre o currículo na prática da escola. Buscamos com isso enfatizar que não somos contrárias à ideia de um currículo base para a educação, mas que ele seja pensado e elaborado a partir dos verdadeiros atores do processo educacional.

\section{O CURRÍCULO NA PRÁTICA DA ESCOLA}

Temos visto, no cenário educacional brasileiro atual, diversas propostas curriculares serem elaboradas, com vistas a renovar a escola brasileira, com o objetivo comum de que mudanças são necessárias para que a qualidade e a equidade sejam garantidas aos estudantes, e entre essas mudanças inovadoras temos a criação de um currículo referência que subsidiará as escolas mineiras.

Recentemente, a BNCC foi homologada, afirmando, em seu texto da quarta versão, que não deve ser considerada como um currículo. Ela se autoconfigura como uma "referência nacional para a formulação dos currículos dos sistemas e das redes escolares dos Estados, do Distrito Federal e dos Municípios” (Brasil, 2017, p. 8). Consideramos, portanto, que esse documento serviu de referência para a elaboração do Currículo Referência de Minas Gerais.

Sabemos que o currículo é um elemento importante para a constituição das escolas como tais e que envolvem muito mais do que conteúdos disciplinares. Moreira e Silva Júnior (2016) asseveram que os currículos envolvem "os espaços/ tempos em que os sujeitos interagem, as ações escolares e culturais" (Moreira e Silva Júnior, 2016, p. 48). Os autores destacam que um currículo deve, sim, contribuir para que a escola se consolide como local de construção e reconstrução de conhecimentos para o desenvolvimento da autonomia de seus estudantes; entretanto, não se deve deixar de dar ênfase ao agir docente exercido pelo professor, que deve ser reconhecido como um profissional que conhece e ensina os conteúdos curriculares.

Assim, reforçamos, embasadas pelo ISD, que o currículo, ao reconhecer o professor como um ser que tem intenções e razões para agir, e não um mero executor das suas prescrições, está considerando-o como um verdadeiro ator do processo educativo. O currículo molda e é moldado pelo docente em sua prática, exercendo, assim, influência recíproca. Por isso, defendemos que o professor é um sujeito central em qualquer discussão sobre o currículo, pois ele é responsável por gerir suas ações no contexto da realidade de seu trabalho e o currículo deve estar em concordância com esse ambiente para ser efetivamente considerado.

Todas essas discussões nos permitem questionar se o Currículo Referência de Minas Gerais traz em seu conteúdo essas considerações sobre as peculiaridades da escola e concebe o professor como esse sujeito central, com intenções e razões próprias para agir. 
Para Garcia-Reis (2007), as propostas curriculares são documentos que trazem os objetivos do ensino da educação formal e de todos os envolvidos nesse processo. Nessa perspectiva, consideramos que esse documento é de suma importância para a organização dos conteúdos a serem ensinados. No entanto, como acredita Barros (2010), um currículo não pode ser idealizado repentinamente. Ele é objeto de reflexões e debates, discussões e articulações, produto de um processo complexo, e não de uma simples resolução.

Nesse sentido, o currículo sempre será parte de uma seleção de conhecimentos feita por alguém sobre o que considera ser legítimo ensinar, contrariando, assim, sua perspectiva de neutralidade. Não faz sentido defender um currículo que não foi pensado a partir do "chão da escola", ou seja, da sua realidade, em conjunto com seus pares. Consideramos, com isso, que um currículo referência para o estado de Minas Gerais só faz sentido se as mudanças concebidas forem parte de um trabalho colaborativo entre professores das escolas estaduais, o que não parece ter acontecido.

De acordo com os apontamentos de Arroyo (1999), as intervenções vindas de reformas oficiais, idealizadas por órgãos governamentais competentes para parecerem mais democráticas, criam canais para que os professores deem sugestões e proponham modificações ao longo do seu planejamento e da sua elaboração, para que se sintam comprometidos com elas, mais que isso, para que se sintam parte delas e as adaptem à realidade da sua escola.

O Currículo Referência de Minas Gerais afirma que os professores da rede mineira de educação participaram da sua elaboração por meio de consultas públicas on-line, conforme observamos:

Contou também com o processo de consulta pública on-line e encontros municipais realizados nos diversos territórios em parcerias entre as redes de ensino, onde educadores e comunidade escolar puderam debater a versão preliminar do documento e apresentar propostas para ampliá-lo. (Minas Gerais, 2018, p. 8)

Entendemos que esse processo participativo não foi efetivo, pois, ao fim das ditas consultas, não houve retorno das entidades governamentais sobre quais sugestões foram acatadas ou não e o porquê, como também constatou Ximenes (apud Machado, 2017), ao analisar o processo de consulta pública sobre a BNCC. De acordo com o autor, acreditamos que houve um processo de instrumentalização da participação de quem buscou contribuir para a elaboração do referido documento.

Depois de nos referirmos ao contexto de produção do Currículo Referência de Minas Gerais, ao ISD e aos seus estudos sobre trabalho, bem como aos textos prescritivos, às propostas curriculares e à sua relação com a escola, apresentaremos, em seguida, os caminhos metodológicos desta pesquisa e, posteriormente, a análise do documento em questão.

\section{CAMINHOS METODOLÓGICOS}

O presente trabalho teve como objetivo central desenvolver uma análise do documento recentemente homologado e divulgado pela SEE/MG, o Currículo 
Referência de Minas Gerais, a fim de detectar o estatuto do trabalho docente nele representado. Nossa motivação maior está diretamente relacionada às preocupações centrais que permeiam o sistema educacional brasileiro neste momento, pois percebemos uma tentativa de esvaziamento profissional do docente, tratando o professor como um coadjuvante no processo educativo e, até mesmo, suprimindo a dimensão profissional nas discussões educacionais.

Consideramos, assim como Bronckart (2008), que todo agir linguageiro se traduz em um determinado texto, definido como "unidade de produção verbal" (Bronckart, 2008, p. 87) que transmite uma mensagem direcionada a um destinatário, visando produzir um efeito de coerência sobre ele. Verificamos que o referido documento é permeado por um agir linguageiro direcionado a um destinatário, o professor.

Diante de tantas tensões e discussões sobre o que deve ser ensinado, nos colocamos a refletir sobre os atores desse processo educacional, em especial o professor. A partir disso, nos dispomos a analisar como o trabalho docente é tratado pelo currículo, qual o estatuto do professor que está nele proposto. Para essa discussão, fizemos um recorte do Currículo Referência de Minas Gerais e analisaremos sua parte introdutória. Usaremos aportes teóricos metodológicos do ISD, com a perspectiva de esclarecer o real papel dos docentes nesse documento. Buscamos também justapor ao ISD pressupostos compatíveis de outras vertentes teóricas, como a Ergonomia da Atividade (Amigues, 2004) e a Clínica da Atividade (Clot, 2007), para nos auxiliar a esclarecer conceitos e dar suporte às reflexões.

Machado et al. (2009) consideram que, além da adoção dos procedimentos metodológicos advindos do ISD, é importante a construção de conceitos que nos auxiliem a abordar questões referentes ao agir com mais propriedade. Dessa forma, as autoras salientam que, ao analisarmos um texto, inicialmente livre de qualquer interpretação, devemos utilizar algumas terminologias. Para apreender os diferentes graus de explicitação do agir prescrito, acreditamos ser pertinente o esclarecimento de alguns termos utilizados por Machado et al. (2009) e apropriados por nós ao longo do texto. Assim, explicitaremos os usos dos termos agir, ação e atividade, e de alguns elementos constitutivos do agir.

As expressões agir e actante são termos que podem ser considerados "neutros" e referem-se ao conjunto de condutas individuais a partir de atividades coletivas de trabalho e dos seres que as realizam. Fazem referência aos "objetos" das análises construídas sobre as condutas observáveis dos seres humanos e são utilizados para se referir a qualquer intervenção humana no mundo feita por um indivíduo (agir individual) ou por vários (agir coletivo) (Machado e Bronckart, 2009).

Com relação aos termos ator, agente, ação e atividade, Bronckart (2008) propõe que eles sejam utilizados para nomear interpretações sobre o actante ou sobre $o$ seu agir. Assim, Machado e Bronckart (2009) argumentam que, para interpretarmos o agir como uma ação ou uma atividade desenvolvida por um só ator ou vários atores, devemos considerar interpretações do agir que atribuam ao actante razões (determinantes externos ou motivos individuais), intenções (finalidades coletivas ou objetivos particulares) e determinados recursos internos e externos para o agir. 
Entendemos, ancoradas nas pesquisas de Machado et al. (2009), que os determinantes externos se configuram como razões extrínsecas aos indivíduos que os levam a agir e que podem ser de diferentes tipos - materiais, simbólicos, de ordem social, institucional etc. Já os motivos são razões de ordem interna, interiorizados por uma ou várias pessoas, levando-as realizar uma ação ou uma atividade.

Com relação à intencionalidade do agir ou aos efeitos que se espera obter, consideramos, em consonância com Machado et al. (2009), que eles podem apresentar-se nos textos sob duas formas: como finalidades que se referem às representações de um indivíduo ou de vários acerca dos efeitos que esperam alcançar sobre objetos ou sobre outros indivíduos, por meio de um agir coletivo; e a partir de intenções que se constituem como representações de um indivíduo ou de vários sobre o efeito que esperam alcançar sobre objetos ou sobre outros indivíduos, por meio de um agir individual.

A respeito dos recursos para o agir, também foram identificados dois tipos: ou eles são instrumentos/ferramentas, recursos externos ao indivíduo presentes no ambiente social que podem, ou não, estar disponíveis para o seu agir; ou são capacidades que se referem aos recursos internos do agente, mentais ou comportamentais, ou seja, recursos cognitivos (Machado et al., 2009).

Dessa forma, as autoras afirmam que podemos chegar a conclusões sobre o agir coletivo ou individual a partir da análise de determinado texto que busque verificar como são colocadas, ou não, as razões, a intencionalidade e os recursos para o agir e sobre o papel que é atribuído aos actantes presentes no texto.

Ressaltamos que, se no agir não forem atribuídos aos actantes razões, intenções e recursos, deve-se substituir o termo actante pelo termo agente, a quem essas propriedades não são atribuídas. Essas diferentes interpretações do agir são construídas em textos que prefiguram a ação humana e não há um limite claro, bem sinalizado, nesses textos sobre esses termos. Portanto, os pesquisadores consideram que, ao interpretar um texto, estamos interpretando também as figuras de ação nele implícitas, a ação humana (Machado et al., 2009).

$\mathrm{Na}$ seção seguinte, traremos alguns excertos retirados do Currículo Referência de Minas Gerais e os analisaremos a partir do procedimento metodológico descrito anteriormente, a Semântica do Agir.

\section{ANÁLISE DO CURRÍCULO REFERÊNCIA DE MINAS GERAIS}

Inicialmente, de forma mais geral, partindo de uma análise macrotextual, identificamos características bem explícitas do documento analisado. Um conjunto de componentes presentes na parte introdutória do documento ressalta seu caráter oficial, visto que ele emerge de uma instância governamental, cujo núcleo é a SEE/ MG, e está articulado com diversas secretarias e municípios.

No que se refere à atribuição do estatuto de autor, observamos que ele é explicitamente atribuído à SEE/MG, entretanto há referência a todas as pessoas que contribuíram para a sua produção, de acordo com o papel que nela desempenharam.

Antes do texto introdutório, o documento faz menção a todos os membros que participaram da sua elaboração, os nomes e as funções que cada um ocupa no 
cenário educacional brasileiro, a Secretaria de Estado de Educação e os diversos setores que a compõem, as secretarias municipais de ensino, as universidades, entre outros. Machado e Bronckart (2005) consideram em suas pesquisas que o conjunto desses elementos permite-nos confirmar o caráter institucional e hierarquizado das instâncias das quais o documento provém e, além disso, a tentativa de distanciamento das instituições governamentais oficiais de educação em relação à responsabilidade sobre o agir prescrito e ao conteúdo das prescrições.

Pela ótica da pesquisa feita por Bronckart e Machado (2004), identificamos que a motivação geral do documento é promover uma oferta de educação pública, inclusiva, com qualidade e equidade, como pode ser notado no seguinte excerto:

A defesa de um sistema de educação único funda-se na integralidade do atendimento e no reconhecimento conjunto da oferta de uma educação pública inclusiva, com qualidade e equidade. [...] trata-se de não distinguir a qual rede um estudante se vincula ao longo da trajetória escolar. (Minas Gerais, 2018, p. 2)

Entretanto, pontuamos a relação intrínseca entre as experiências proporcionadas pela escola e o processo de constituição das identidades dos sujeitos. Em virtude disso, toda e qualquer ação governamental que preconize a normatização dos currículos deve ser analisada com profundidade e cautela (Neira, 2018). Entendemos que o texto analisado apresenta um objetivo idealizado, demonstrando desconhecimento sobre a realidade escolar, fazendo-nos inferir que seus criadores não são sujeitos conhecedores do real funcionamento da escola, das dimensões de uma aula, configurando o documento como utópico, pois isso é pensar em uma escola idealizada, inexistente.

Embora o Plano Nacional de Educação (Brasil,2014) proponha a elaboração de uma Base Nacional Comum Curricular e também a organização curricular dos municípios, pois acredita na existência de conteúdos mínimos a serem trabalhados, na conquista de capacidades e habilidades mínimas pelos estudantes, isso não significa que deve haver padronização do trabalho que é feito em uma escola e outra, mesmo sendo escolas pertencentes à mesma rede de ensino, visto que cada escola tem suas particularidades.

Outros aspectos que acreditamos serem importantes ressaltar são a orientação argumentativa, marcada por sequências argumentativas na estrutura inicial do documento, e a preocupação em não fomentar posicionamentos contrários à sua implementação na rede de ensino. De forma bastante evidente, essas sequências confirmam que o objeto temático pode ser considerado controverso, passível de contradições e posições diferentes, e buscam, dessa forma, convencer o seu destinatário sobre a verdade das proposições teóricas e metodológicas nele vinculadas. A posição é a de que a implementação de um currículo comum ao estado de Minas Gerais é uma excelente alternativa para melhorar a qualidade da educação.

Os argumentos utilizados para convencer o leitor são notados quando o texto traz informações sobre o fato de ter sido submetido a um conjunto de determinações externas provenientes de fatos indiscutíveis e evoluções sociais e econômicas, bem como de características gerais do estado ao qual se destina. De acordo com o texto 
introdutório, o seu processo de produção contou com a participação de mais de 3.100 escolas e 120 mil profissionais, pesquisadores e estudiosos experientes, e toda essa projeção contribuiria de forma indiscutível para que o trabalho do professor fosse mais significativo e para que houvesse melhoria da educação, ao executar o currículo em suas salas de aula.

Outra estratégia argumentativa utilizada para reforçar a necessidade de uma reforma curricular constituiu-se em torno de argumentos implícitos sobre a inadequação dos currículos existentes, como notamos no seguinte trecho: "ao assumir esta proposta de currículo integrado, a escola está se propondo a mudar, a se transformar" (Minas Gerais, 2018, p. 18).

Constatamos também a presença de um discurso interativo na tentativa de buscar uma aproximação maior entre o documento e seu destinatário, como no seguinte trecho: "Esperamos que deste documento, que ora lhe apresentamos e que orienta a elaboração dos planos e ações educacionais em Minas Gerais, surjam, da prática de cada educador e de cada escola, formas de implementação de uma educação inclusiva, igualitária e democrática” (Minas Gerais, 2018, p. 3).

Em recente roda de conversa na Universidade Federal de Juiz de Fora, o professor António Nóvoa discursou sobre alguns aspectos relacionados à formação e ao trabalho dos professores e, entre eles, destacou a desvalorização desses profissionais e seu estatuto, não só no Brasil, mas em diferentes países. Ele ressalta que a palavra professor vem sendo substituída por outras palavras, como educador, profissional do ensino, recreador, entre outras, assinalando uma tentativa de esvaziamento da docência e de sua dimensão profissional. No texto em análise, encontramos menções ao alvo da prescrição (o professor) de forma generalizada e superficial, e, muitas vezes, a palavra professor é substituída por educador e leitor, como podemos observar no excerto supracitado. $\mathrm{O}$ menor número de ocorrências da palavra professor confirma nossa percepção, uma vez que ela foi encontrada nove vezes no texto, enquanto educador aparece dezenove vezes e docente, nove vezes, o que confirma a assertiva de Nóvoa.

A partir do seguinte excerto,

Apresentamos, assim, os eixos estruturadores que embasaram a construção do Currículo Referência de Minas Gerais e, em seguida, as etapas de ensino - Educação Infantil e Ensino Fundamental - áreas do conhecimento, as unidades temáticas, os objetos de conhecimento e as habilidades a serem desenvolvidos durante todo o percurso escolar, definindo os melhores caminhos para que o processo de ensino e aprendizagem aconteça em todos os seus tempos: nas infâncias, nas adolescências e nas juventudes... Espera-se que a BNCC, o Currículo Referência de Minas Gerais e o [projeto político-pedagógico] PPP de cada escola indiquem caminhos para que aulas sejam pensadas, planejadas e executadas, (Minas Gerais, 2018, p. 11, grifos nossos)

Entendemos que há certa contradição relacionada aos atores do trabalho docente, pois ora é o conjunto de conteúdos do currículo mineiro que definirá o processo de ensino, ora são os três documentos (BNCC, Currículo de MG e 
o projeto político-pedagógico de cada escola) que indicarão os caminhos para o planejamento das aulas. Definir e indicar são verbos cujos sentidos se diferenciam quanto à responsabilidade atribuída aos seus sujeitos, revelando contradição em seu propósito enunciativo.

Sobre o estatuto atribuído ao professor no Currículo Referência, observamos que, muitas vezes, é dada a ele uma posição de adjuvante ou instrumento de um processo de ensino, assim como observado por Machado (2007). Podemos notar que o estatuto de agente, e não de ator, na atividade do trabalho docente permanece, uma vez que a compreensão é a de que esse trabalho é quase que mecânico, de aplicação de conteúdos, metodologias e princípios prescritos. O professor, no documento do entorno-precedente ao agir em análise, é aquele que desenvolve e executa aquilo que está posto, e o estatuto de ator do processo educativo recai sobre o próprio documento.

Afirmações do tipo "o professor deve 'se apropriar do documento" (Minas Gerais, 2018, p. 21) e "o currículo é certamente central, pois diz respeito àquilo que o professor precisa desenvolver em seu cotidiano" (Minas Gerais, 2018, p. 21) reforçam a ideia de um currículo protagonista, com perspectiva aplicacionista de ensino, negando o papel de ator ao professor e trazendo uma representação negativa sobre seu trabalho, ao mencionar que ele precisa se apropriar do documento em sua atividade profissional.

O seguinte excerto também nos chamou a atenção:

Espera-se que a BNCC, o Currículo Referência de Minas Gerais e o PPP de cada escola indiquem caminhos para que aulas sejam pensadas, planejadas e executadas a partir das premissas do trabalho em grupo, da convivência com as diferenças, da superação dos obstáculos e do exercício pleno da autonomia, garantindo a correlação do currículo com o trabalho pedagógico da escola e seu corpo docente. (Minas Gerais, 2018, p. 11)

A partir desse trecho, podemos reafirmar nosso posicionamento acerca da agentivização do professor no processo educativo proposto pelo documento, ao passo que os verdadeiros atores são os documentos. Entretanto, podemos perceber certa intencionalidade discursiva ao propor que o professor precisa ser autônomo, mas ele não tem, na prática, essa autonomia, já que em grande parte do texto introdutório ele é considerado como aquele que cumpre o que o texto prescreve.

Percebemos, assim, que ora o documento trata o professor como mero executor, ora dá a ele certa autonomia, evidenciando, novamente, incoerência em seu interior. Essa incoerência entre os propósitos discursivos de textos do entorno-precedente ao agir já foi demonstrada por Garcia-Reis (2017), em análise Projeto Pedagógico do Curso de Letras da UFJF. Tal característica pode ser considerada uma estratégia argumentativa desses textos, ao não assumirem claramente a ausência de atorialidade na atividade de trabalho do professor.

O seguinte trecho também corrobora a afirmação de que o professor não é o protagonista, mas sim um beneficiário ou um destinatário do documento: 
Por fim, estes três documentos (BNCC, Currículo, PPP) devem estar inseridos, direta e indiretamente, no Plano de Aula dos professores, permitindo que todo o arcabouço legal, conceitual e material discutido possa se efetivar em sala de aula, ou fora dela, no processo de ensino e aprendizagem com os estudantes. (Minas Gerais, 2018, p. 13, grifo nosso)

Podemos observar que os atores do processo de ensino seriam a BNCC, o Currículo Referência de Minas Gerais e o PPP das escolas, visto que são colocados como atores centrais do processo de prescrição e considerados instrumentos desencadeadores de ações desejadas pela fonte prescritora, ao esperar que eles sirvam de instrumentos para o desenvolvimento do agir docente (Machado e Bronckart, 2005).

Portanto, entendemos que o estatuto do professor nesse texto é de quem executa aquilo que foi planejado para ele, já que a atorialidade está nos documentos, semelhantemente a outras pesquisas realizadas, como a de Machado e Bronckart (2005), por exemplo. Desse modo, o Currículo Referência de Minas Gerais apresenta significativa contradição com as Diretrizes Curriculares Nacionais de Formação de Professores (Brasil, 2015), ao conceber o professor como ator do processo educativo (Garcia-Reis, 2020). A ideia trazida por ele mostra-se equivocada, apesar de amplamente disseminada, segundo a qual está no trabalho do professor a grande fonte do fracasso da aprendizagem dos alunos.

Outro aspecto a considerar e que se faz presente no trecho analisado é a figura do professor como um super-homem (Machado, 2007), capaz de resolver todos os problemas dos alunos, dentro e fora da sala de aula, atribuindo-lhe múltiplas tarefas. Em virtude disso, o professor em exercício é tachado como despreparado para esse trabalho, pois agir dessa forma configura-se como verdadeiro desafio.

A necessidade de cumprimento das prescrições curriculares e a pouca autonomia na condução do seu trabalho estariam relacionadas a uma ruptura da subjetividade do professor (Clot, 2007), constituindo-se na amputação do seu poder de agir, claramente observada no excerto em destaque, extraído da página 13 do documento. Essa amputação do trabalho docente acaba ocasionando um mal-estar docente, que acompanha a crise de identidade profissional dos professores, por serem considerados responsáveis pelo fracasso escolar e por não conseguirem atender às exigências das instituições e da sociedade em geral, sem considerar que muitos desses problemas são, na verdade, de ordem social (Machado e Abreu-Tardelli, 2009). Entretanto, nos apoiando nos fundamentos teóricos de Clot (2007), acreditamos que o problema está no fato de as instituições não atenderem às reais necessidades dos trabalhadores da educação, pois, muitas vezes, lhes é negada voz ativa e participativa, sem o reconhecimento de sua real contribuição.

Associamos a isso o fato de que a introdução de novas prescrições para os trabalhadores de um determinado ofício sempre afeta de uma forma ou de outra o gênero da atividade que o caracteriza (Machado e Abreu-Tardelli, 2009). Sobre isso, Clot (2007) assevera que quando isso ocorre pode haver perturbação grave para as regras coletivas já estabelecidas, pois fragiliza o gênero de atividade que guia o agir do trabalhador. $\mathrm{O}$ autor entende que, se as prescrições produzidas pelas instituições não se respaldarem no gênero da atividade que já é seguido pelos trabalhadores, elas 
podem levar a uma desregulação da ação individual, gerando "déficit instrumental" e ocasionando sentimento de impotência.

O trecho "é nesse sentido que você, educador(a), tem papel fundamental na re(leitura) do documento curricular aqui apresentado e na sua efetiva implementação no contexto escolar"(Minas Gerais, 2018,p. 17) sugere-nos o entendimento de que o professor não está preparado para as novas exigências educacionais, contribuindo para a desvalorização da profissão docente, visto que ele precisa se apropriar do documento para garantir os direitos de aprendizagem de seus alunos, interpretação também possível a partir do trecho a seguir:

A implementação do Currículo Referência de Minas Gerais demanda aos profissionais da educação, especialmente aos docentes, conhecer e se apropriar do documento aqui apresentado, dos conceitos e terminologias nele presentes para que o trabalho em sala de aula realmente se alinhe aos direitos de aprendizagem previstos em sua organização. (Minas Gerais, 2018, p. 21, grifo nosso)

Constatamos também que esse trecho pressupõe a existência de um agir anterior ao prescritivo que não está funcionando e vem trazendo muitos entraves para consolidar uma educação de qualidade. Dessa maneira, haveria uma crença em um agir docente - consolidado posteriormente ao que está posto e prescrito no Currículo Referência de Minas Gerais - capaz de corrigir esses déficits e contribuir sobremaneira para uma melhoria na educação mineira em geral.

\section{CONSIDERAÇÕES FINAIS}

A análise do Currículo Referência de Minas Gerais realizada possibilitou-nos, a partir da interpretação do texto introdutório do referido documento, responder nossos questionamentos a respeito do estatuto do trabalho docente delineado e da responsabilidade atribuída ao professor. $\mathrm{O}$ texto introdutório revelou-nos que os professores são actantes do processo educacional, ao ocuparem a posição de agentes, ou seja, não são considerados atores reais do processo de ensino, com motivos e intenções próprias, são postos como executores dos princípios, conteúdos e metodologias que estão ali prescritos.

Entendemos, assim como Machado e Bronckart (2009), que o verdadeiro ator do processo de ensino é o próprio documento, visto como o instrumento mais importante do trabalho a ser realizado, e que ao professor cabe a responsabilidade de aplicá-lo em um processo quase que mecânico. Dessa maneira, o professor é agentivizado e representado como elo de um processo no qual não lhe é atribuída a responsabilidade de ator.

Esses resultados assemelham-se àqueles de Machado (2007), Machado e Abreu-Tardelli (2009), Machado e Bronckart (2005), ao revelarem que a maioria dos textos do entorno-precedente ao agir tem negado o estatuto de ator aos professores, compreendendo-os implícita ou explicitamente como meros agentes do processo de ensino-aprendizagem. Nesse contexto, somos levados a acreditar que as próprias instituições governamentais educacionais prescritoras acabam 
sustentando a imagem negativa e uma crise de identidade profissional do professor, contribuindo ainda mais para a desvalorização da profissão docente (Machado e Bronckart, 2005).

Como vemos, a premissa de não cumprir aquilo que está prescrito tem sugestionado um déficit no trabalho do professor, que poderia ser superado se a orientação prescrita pelas instituições educacionais oficiais para a realização do seu trabalho fosse seguida. Ressaltamos, entretanto, em conformidade com Machado (2007), que o verdadeiro déficit não está no professor, mas nas prescrições e nas condições de trabalho oferecidas, que impedem a realização do seu agir profissional, comprometendo, inclusive, seu desenvolvimento particular.

Diante disso, identificamos que o Estado assumiu o papel de estabelecer os objetivos do sistema educacional mineiro e de definir os critérios de qualidade a serem buscados, enquanto às instituições e aos professores cabe o papel de decidir a melhor forma de responder às expectativas governamentais.

Em síntese, acreditamos que análises de textos do entorno-precedente ao agir, como a que empreendemos, podem trazer, além de compreensões sobre o trabalho docente, representações que estão sendo construídas sobre ele. Assim, ler, interpretar, discutir e confrontar posicionamentos alocados em textos prescritivos, ora para consolidar ideias, ora para reformulá-las, poderão consolidar transformações nesse métier e possibilitar a emergência da atorialidade nos profissionais da docência.

\section{REFERÊNCIAS}

AMIGUES, R. Trabalho do professor e trabalho de ensino. In: MACHADO, A. R. (org.). O ensino como trabalho: uma abordagem discursiva. Londrina: Eduel, 2004. p. 35-53.

ARROYO, M. Experiências de inovação educativa: o currículo na prática da escola. In: MOREIRA, A. F. B. M. (org.). Currículo: políticas e práticas. Campinas: Papirus, 1999. p. 131-164.

BARROS, E. M. D. Vozes e temas que perpassam o discurso curricular do curso de Letras. Acta Scientiarum. Language and Culture, Maringá, v. 32, n. 2, p. 199-213, dez. 2010. https://doi.org/10.4025/actascilangcult.v32i2.9341

BRASIL. Constituição da República Federativa do Brasil de 1988. Brasília: Senado Federal, 1988.

BRASIL. Lei no 9.394, de 20 de dezembro de 1996. Estabelece as diretrizes e bases da educação nacional. Brasília, 1996.

BRASIL. Ministério da Educação. Secretaria de Articulação com os Sistemas de Ensino. Plano Nacional de Educação. Brasil: MEC, 2014.

BRASIL. Resolução CNE/CP no 2, de $1^{\circ}$ de julho de 2015. Define Diretrizes Curriculares Nacionais para a formação em nível superior (cursos de licenciatura, cursos de formação pedagógica para graduados e cursos de segunda licenciatura) e para a formação continuada. Diário Oficial da União, Brasília, 2 jul. 2015. 
BRASIL. Base Nacional Comum Curricular: educação é a base. Brasília: MEC, 2017. Disponível em: http://basenacionalcomum.mec.gov.br/abase/. Acesso em: 5 jun. 2019. BRONCKART, J.-P. Atividade de linguagem, discurso e desenvolvimento humano. Campinas: Mercado de Letras, 2006.

BRONCKART, J.-P. O agir nos discursos: das concepções teóricas às concepções dos trabalhadores. Campinas: Mercado de Letras, 2008.

BRONCKART, J.-P.; MACHADO, A. R. Procedimentos de análise de textos sobre o trabalho educacional. In: MACHADO, A. R. (org.). O ensino como trabalho: uma abordagem discursiva. Londrina: Eduel, 2004. p. 131-163.

CLOT, Y. A função psicológica do trabalho. 2 ed. Rio de Janeiro: Vozes, 2007.

DOLZ, J.; GAGNON, R. O gênero, uma ferramenta didática para desenvolver a linguagem oral e escrita. In: BUENO, L.; COSTA-HÜBES, T. C. (org.). Gêneros orais no ensino. Campinas: Mercado de Letras, 2015. p. 23-56.

GARCIA-REIS, A. R. Práticas de linguagem na formação dos professores de Língua Portuguesa: uma perspectiva de análise do Projeto Pedagógico do curso de Letras. Veredas - Interacionismo Sociodiscursivo, Juiz de Fora, v. 21, n. 3, p. 246-260, jan. 2017. https://doi.org/10.34019/1982-2243.2017.v21.28004

GARCIA-REIS, A. R. A concepção do trabalho docente em documentos prescritivos. Reflexão e Ação, Santa Cruz do Sul, v. 28, n. 2, p. 89-103, maio/ago. 2020. https://doi. org/10.17058/rea.v28i2.14299

GARCIA-REIS, A. R.; GODOY, A. R. G. L. O ensino de leitura nos anos iniciais do ensino fundamental: a proposta da Base Nacional Comum Curricular. Currículo Sem Fronteiras, v. 18, n. 3, p. 1025-1043, set./dez. 2018.

JACOB, A. E.; DIOLINA, K.; BUENO, L. Os gêneros orais na penúltima versão da Base Nacional Comum Curricular: implicações para o ensino. Horizontes, v. 36, n. 1, p. 85-104, abr. 2018. https://doi.org/10.24933/horizontes.v36i1.585

MACHADO, A. R. Por uma concepção ampliada do trabalho do professor. In: GUIMARÃES, A. M. M.; MACHADO, A. R.; COUTINHO, A. (org.). O interacionismo sociodiscursivo: questões epistemológicas e metodológicas. Campinas: Mercado de Letras, 2007. p. 77-97.

MACHADO, A. R. Trabalho prescrito, planificado e realizado na formação de professores: primeiro olhar. In: MACHADO, A. R.; ABREU-TARDELLI, L. S.; CRISTOVÃO, V. L. L. (org.). Linguagem e educação: o trabalho do professor em uma nova perspectiva. Campinas: Mercado de Letras, 2009. p. 79-99.

MACHADO, A. R.; ABREU-TARDELLI, L. S. Textos prescritivos da educação presencial e a distância: fonte primeira do estresse do professor? In: MACHADO, A. R.; ABREU-TARDELLI, L. S.; CRISTOVÃO, V. L. L. (org.). Linguagem e educação: o trabalho do professor em uma nova perspectiva. Campinas: Mercado de Letras, 2009. p. 101-116.

MACHADO, A. R.; ABREU-TARDELLI, L. S.; CRISTOVÃO, V. L. L. (org.). Linguagem e educação: $o$ trabalho do professor em uma nova perspectiva. Campinas: Mercado de Letras, 2009. 
MACHADO, A. R.; BRONCKART, J.-P. De que modo os textos oficiais prescrevem o trabalho do professor? Análise comparativa de documentos brasileiros e genebrianos. DELTA, v. 21, n. 2, p. 183-214, 2005. https://doi.org/10.1590/S010244502005000200002

MACHADO, A. R.; BRONCKART,J.-P.(Re-)configurações do trabalho do professor construídas nos e pelos textos: a perspectiva metodológica do grupo ALTER-LAEL. In: MACHADO, A. R.; ABREU-TARDELLI, L. S.; CRISTOVÃO, V. L. L. (org.). Linguagem e educação: $o$ trabalho do professor em uma nova perspectiva. Campinas: Mercado de Letras, 2009. p. 31-77.

MACHADO, A. R.; CRISTOVÃO, V. L. L. Representações sobre o professor e seu trabalho em proposta institucional brasileira para a formação docente. In: MACHADO, A. R.; ABREU-TARDELLI, L. S.; CRISTOVÃO, V. L. L. (org.). Linguagem e educação: o trabalho do professor em uma nova perspectiva. Campinas: Mercado de Letras, 2009. p. 117-136.

MACHADO, A. R. et al. Relações entre linguagem e trabalho educacional: novas perspectivas e métodos no quadro do interacionismo sociodiscursivo. In: MACHADO, A. R.; ABREU-TARDELLI, L. S.; CRISTOVÃO, V. L. L. (org.). Linguagem e educação: $o$ trabalho do professor em uma nova perspectiva. Campinas: Mercado de Letras, 2009. p. 15-29.

MACHADO, K. Entrevista: Salomão Ximenes. "Temos um documento tecnocrático e conservador, produzido sem transparência". Escola Politécnica de Saúde Joaquim Venâncio, 2017. Disponível em: http://www.epsjv.fiocruz.br/noticias/entrevista/temosum-documento-tecnocratico-e-conservador-produzido-sem-transparencia. Acesso em: 6 jun. 2019.

MAGALHÃES, T. G.; CRISTOVÃO, V. L. L. Sequências e projetos didáticos no Pacto Nacional pela Alfabetização na Idade Certa. Campinas: Pontes, 2018.

MINAS GERAIS. Resolução no 666/2005, de 7 de abril de 2005. Estabelece os conteúdos básicos comuns a serem obrigatoriamente ensinados pelas unidades de ensino estaduais que oferecem as series finais do fundamental e o ensino médio. Belo Horizonte: Secretaria de Estado da Educação, 2005.

MINAS GERAIS. Currículo Referência de Minas Gerais. Minas Gerais, 2018. Disponível em: http://www2.educacao.mg.gov.br/images/documentos/20181012\%20 -\%20Curr\%C3\%ADculo\%20Refer\%C3\%AAncia\%20de\%20Minas\%20Gerais\%20 vFinal.pdf. Acesso em: 5 jun. 2019.

MOREIRA, A. F.; SILVA JÚNIOR, P. M. Currículo, transgressão e diálogo: quando outras possibilidades se tornam necessárias. Tempos e Espaços em Educação, Sergipe, v. 9, n. 18, p. 45-54, jan./abr. 2016. https://doi.org/10.20952/revtee.v9i18.4962

NEIRA, M. G. Essa base, não. Jornal da USP, São Paulo, 19 set. 2018. Disponível em: https://jornal.usp.br/artigos/essa-base-nao/. Acesso em: 5 jun. 2019.

SAUJAT, F. O trabalho do professor nas pesquisas em educação: um panorama. In: MACHADO, A. R. (org.). O ensino como trabalho: uma abordagem discursiva. Londrina: Eduel, 2004. p. 4-34. 


\section{SOBRE AS AUTORAS}

Andreia Rezende Garcia-Reis é doutora em linguística pela Universidade Federal do Rio de Janeiro (UFRJ). Professora da Universidade Federal de Juiz de Fora (UFJF).

E-mail: andreiargarcia@yahoo.com.br

Giovana Rabite Callian é mestranda em educação pela Universidade Federal de Juiz de Fora (UFJF). Professora da rede estadual de educação de Minas Gerais.

E-mail: giovanna_callian@hotmail.com

Conflitos de interesse: As autoras declaram que não possuem nenhum interesse comercial ou associativo que represente conflito de interesses em relação ao manuscrito.

Financiamento: $\mathrm{O}$ estudo não recebeu financiamento.

Contribuições dos autores: Administração do Projeto, Análise Formal, Conceituação, Curadoria de Dados, Escrita - Primeira Redação, Escrita - Revisão e Edição: Garcia-Reis, A.R. Escrita - Revisão e Edição: Callian, G.R.

Recebido em 22 de março de 2020

Aprovado em 20 de julho de 2020 